\title{
Assessing General Knowledge of Agricultural Students in Zanjan University, Iran
}

\author{
Kolsoum Hamidi ${ }^{1}$, Parisa Najafloo ${ }^{1}$ and Jafar Yaghoubi $^{1}$
}

\begin{abstract}
-the purpose of this study was measuring students' general knowledge of agriculture in Zanjan University, Iran. Descriptive survey method was used in this research. The graduate and undergraduate students in the Faculty of Agriculture formed the population of this study $(\mathrm{N}=709)$. The sample size was estimated by using Cochran's formula $(n=109)$. Samples were selected by stratified random method. The research tool was a questionnaire. Validity of the instrument confirmed by academic members and other related experts. The reliability was determined by pilot test and calculating Cronbach's alpha coefficients (0.81). Data were analyzed using SPSS20. Results of students' classification based on their knowledge score related to agriculture showed that the majority of students $(76.2 \%)$ had low general knowledge in related to agriculture. So there is need to make fundamental changes in all part of agricultural higher education system.
\end{abstract}

Index Terms - Agricultural higher education, General knowledge, Student, Zanjan university.

\section{INTRODUCTION}

In recent decades the higher education system of Iran has expanded acceptance of students rapidly. There are over 100 higher education institutions including 30 universities, 14 colleges, 5 private colleges, and 36 higher education centers for in-service training of government employees [8]. Based on current statistics, Iran has a student population of almost 4.5 million in total higher education courses [3]. During the last 20 years the graduates of higher education in Iran has increased 5 times. Statistics show an increase in students in the Department of Agriculture as well as [1]. Furthermore, the number of women graduates in agricultural related fields has increased dramatically. Contrary to the growth in admission for higher education, unemployment of university graduates has been increasing in Iran. Despite the high unemployment in the agricultural sector due to limited job opportunities, job preparation for the agricultural sector is one of the most important responsibilities of vocational and technical higher education in Iran [8].

Higher education system is one of the most effective investments in human resources and has a crucial effect on various aspects of society such as social, economic, cultural and political conditions. Therefore, it is important to ensure optimal performance to avoid the waste of human and material resources [2].

Kolsoum Hamidi, Parisa Najafloo and Jafar Yaghoubi they all are with the Department of Extension, Communication and Rural Development, Faculty of Agriculture, Zanjan University, Zanjan, Iran.
Although facts and figures from various sources show quantitative development in the Iran's higher education system, it is not sufficient alone. So quality is an important factor in this regard. The results of studies show that a very large percentage of the students have a low level of general knowledge from their course even after a few semesters, which unfortunately lead to the loss of resources and impose costs to the state and country. Students in agriculture that play an important role in growth of country are no exception [7].

The rapid scientific and technological changes affect all aspects of life in modern humans. Scientific challenges, task complexity and communication systems are evolving. So there is a need to efficient and skillful human resource [6].

"Reference [4] state lack of attention to training and developing general knowledge and skill is one of the weaknesses of universities that intensify the unemployment among university graduates".

"Reference [5] shows that to make relationship between industry and university is one of the factors of competence among students".

Agriculture is a key section of economic development in Iran. General knowledge of agriculture with specialized knowledge and skills is one of the main characteristics of efficient agricultural human resources. Indeed general knowledge of agriculture is critical to help college students try to achieve careers in the food, agriculture, and natural resources industries. This study conducted because of there is a need to know the general knowledge of agricultural students.

\section{Purpose And OBJECtives}

The purpose of the study was to identify the level of general knowledge of agriculture among Agricultural students in the faculty of agriculture at Zanjan University. The objectives of the study were to:

(a) Describe individual and educational characteristics of participants specially experience in agricultural activities, Previous acquaintance with field of study and Motivation for selecting agriculture as a field of study.

(b) Classify Students based on their knowledge score related to agriculture.

\section{Methodology}

This study is a quantitative and practical research. Descriptive survey method was used in this research.

The area of study was Zanjan University in Iran. The graduate and undergraduate students in the Faculty of 
Agriculture in 2013-2014 formed the population of this study $(\mathrm{N}=709)$. The sample size was estimated using Cochran's formula (1) $n=109$.

$$
N=\frac{N(t . s)^{2}}{\mathrm{ND}^{2}+(\mathrm{t} . \mathrm{s})^{2}}
$$

The samples were selected using stratified random sampling, and considering the appropriateness of the number of students in each category.

The data collection tool was a questionnaire that was developed from literature review. The questionnaire consisted of two parts. In the first part, the individual and professional characteristics of the respondents were assessed and in the second part, 20 items were used for measuring the students' general knowledge related to agriculture. The validity of questionnaire was confirmed by the comments of academic members. The reliability was determined by pilot test and calculating Cronbach's alpha coefficients (0.81).

Collected data were analyzed using the Statistical Package for the Social Sciences (SPSS20).

\section{RESULTS}

\section{A. Description of the individual and educational characteristics of respondents}

Based on the results of the research the mean age of participants was 23.5 years. More than half of the respondents were women $(53.2 \%)$. The majority of the participants were from rural areas $(76.1 \%)$. The majority of respondents in the study were undergraduate students $(80.73 \%)$. More than half of the respondents had no experience in agricultural activities. The students' previous acquaintance with their field of study was at a low level and their main motivation for selecting agriculture as a field of study was Just entrance to university (Table I).

TABLE I: DESCRIPTION OF THE INDIVIDUAL AND EDUCATIONAL CHARACTERISTICS OF RESPONDENTS

\begin{tabular}{|c|c|c|c|}
\hline Variables & Group & frequency & percent \\
\hline \multirow{2}{*}{ Gender } & female & 58 & 53.2 \\
\hline & male & 51 & 46.8 \\
\hline \multirow{2}{*}{ Place of birth } & Urban & 26 & 23.9 \\
\hline & Rural & 83 & 76.1 \\
\hline \multirow{2}{*}{$\begin{array}{l}\text { Level of } \\
\text { education }\end{array}$} & MSc & 21 & 19.27 \\
\hline & $\mathrm{BSc}$ & 88 & 80.73 \\
\hline \multirow{2}{*}{$\begin{array}{l}\text { Experience in } \\
\text { agricultural } \\
\text { activities }\end{array}$} & Yes & 50 & 45.4 \\
\hline & No & 59 & 54.6 \\
\hline \multirow{2}{*}{$\begin{array}{l}\text { Motivation for } \\
\text { selecting } \\
\text { agriculture as a } \\
\text { field of study }\end{array}$} & $\begin{array}{l}\text { Just entrance to } \\
\text { university }\end{array}$ & 69 & 73.4 \\
\hline & $\begin{array}{l}\text { Interest in field } \\
\text { of study }\end{array}$ & 25 & 26.6 \\
\hline \multirow{5}{*}{$\begin{array}{l}\text { Previous } \\
\text { acquaintance } \\
\text { with field of } \\
\text { study }\end{array}$} & Very little & 56 & 51.9 \\
\hline & Little & 26 & 24.1 \\
\hline & somewhat & 20 & 18.5 \\
\hline & Much & 5 & 4.6 \\
\hline & Very much & 1 & 9 \\
\hline
\end{tabular}

\section{B. Students' general knowledge related to agriculture}

Students' general knowledge related to agriculture was measured through 20 questions. The results showed that the mean score of the respondents was 10.33 (S.D. $=3.22$ ) on a scale of zero to 20 .
Results of students' classification based on their knowledge score related to agriculture are given in Table II.

TABLE II: DISTRIBUTION OF THE STUDENTS ACCORDING TO THEIR GENERAL KNOWLEDGE SCORE ABOUT AGRICULTURE

\begin{tabular}{|l|l|l|l|}
\hline score & frequency & percent & $\begin{array}{l}\text { Cumulative } \\
\text { percent }\end{array}$ \\
\hline$<10$ & 41 & 37.6 & 37.6 \\
\hline $10-12$ & 42 & 38.6 & 76.2 \\
\hline $13-17$ & 25 & 22.9 & 99.1 \\
\hline$>17$ & 1 & 0.9 & 100 \\
\hline
\end{tabular}

According to results in Table II, the majority of students (76.2\%) had low general knowledge in related to agriculture (score $\leq 12$ ).

\section{CONCLUSIONS}

The general knowledge relating to farming is one of the requirements for career success among staff, who are working in the agricultural sector.

According to the results of this study, more than three quarter of the students had a low level of general knowledge about agriculture and this shows that current state of the agricultural higher education system does not have effect on students' general knowledge. So it is necessary for higher education institutes to improve quality of education through fundamental changes such as the curriculums, teaching and learning methods, materials and contents. Furthermore, a relation between academia and industries or executive agencies in agricultural sector creates a useful position for students to apply and realize their learning in real world. Moreover, an effective student selection system based on interest and talent can be as an approach to improve and enrich the agricultural students' general knowledge.

\section{ACKNOWLEDGMENT}

This study was supported in part by Iran's National Elites Foundation (INEF). Authors thank this organization.

\section{REFERENCES}

[1] H. Shabanalifami, Sh. Aghapour, And A. Alambeigi, "Identify obstacles and problems of job-creation between agricultural students at Tehran University," Journal of Agricultural Economics and Development Research, 41-2(2): 219-229, 2010.

[2] S. Feli, N. Biglari, and Gh. Pezeshkirad, "Factor analysis of component of Tarbiat Modares Students' satisfaction from the quality of educational services," Journal of Agricultural Extension and Education Research, 3, 25-34, 2010.

[3] Saeidi, A. Higher Education Statistics. Institute of Research and Planning in Higher Education. First edition, 2017

[4] P. Nurmi, and K. Paasio, "Entrepreneurship in Finnish universities," Education and training journal, 49(1), 56-66, 2007.

[5] K. B. Patel, M. Mania, J. Hagmann, and P. L. Woomer, "Curriculum development and transformation in rural development and natural resource management," Paper presented at the strategy workshop of the foundation Bellagio center, Italy, 2001.

[6] H. Shabani, "Challenges and approaches of the information age and the need for change in the structure and performance of higher education curricula," The 3rd conference of the curriculum in the age of information and communication technology, 2003. Available on: html.007_CAICT03-CAICT03-Paper/com.civilica.www://https

[7] J. Tofighidarian, "The need to enhance quality in higher education in Iran," $12^{\text {th }}$ National Congress Corporation of Government, Academia and Industry to development. Tehran, 2008. Available on: https://www.civilica.com/Paper-CCGUIND12-CCGUIND12_019.html 
[8] K. Zarafshani, N. A. Knobloch, and H. Aghahi, "General perceived self-efficacy of Iranian college of agriculture students," Journal of International Agricultural and extension education, 15(1), 69-84, 2008.

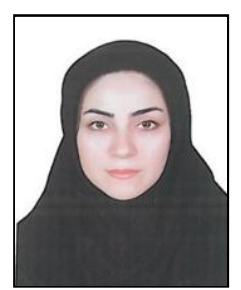

Kolsoum Hamidi was born in 1983 in Zanjan, Iran.

She is PhD student in Agricultural Extension and Education, Department of Extension, Communication and Rural development, Faculty of Agriculture, University of Zanjan, Zanjan, Iran.

She was obtained MSc and BSc in Agricultural Extension and Education from Zanjan University, Zanjan, Iran in 2016 and 2002.

She has worked as an educator and extension agent in the Agriculture Organization of Zanjan province from 2003 to 2011.

She study and research about wide range of matters in domain Agricultural extension and education especially urban agriculture, drought and water management and higher education. Some of her research and publications are:

1. Hamidi, K., \& Yaghoubi, J. (2016). Identification of competencies required for urban agriculture extension agents from the agricultural extension expert's perspective of Zanjan province. Journal of Agricultural Extension and Education Research. 3(35): 23-33

2. Hamidi, K., \& Yaghoubi, J. (2016). Educational needs of urban Farmers from the view point of Zanjan city citizens. Journal of Agricultural Education Administration Research, 39:80-93

3. Hamidi, K., \& Yaghoubi, J. (2017). Farmer's knowledge about drought Management in Zanjanroud Basin of Zanjan Township, Iran. The International Conference on Environment \& Sustainable Development (IC17Malaysia Conference), Kuala Lumpur - Malaysia. 10-12, August 2017.

Ms. Hamidi was awarded the Academic Prize by the Iran's National Elites Foundation (INEF) for her research and educational activities three times in 2015, 2016 and 2017. 